\title{
Hispanic Women's Presence in the Actual U.S. Congress
}

\author{
Antonio Daniel Juan Rubio, Isabel Maria Garcia Conesa \\ Centro Universitario de la Defensa de San Javier, Alicante, Spain
}

\begin{abstract}
The Hispanic population of the United States has become, in recent times, into a powerful electoral force whose vote is historically oriented towards the Democratic Party of the incumbent US President Barack H. Obama. Obviously, this growing electoral strength is reflected into its political presence in the American life that has been accomplished with their numeric inclusion in the US Congress. Although in the recent decades several studies have arisen on the status of the Hispanic community in the United States from both sides of the Atlantic, these have been primarily focused on casuistic, demographic, developmental or educational aspects. But only a few of them, if any, has focused exclusively on the numerical and symbolical representation of the community in the political arena, and more specifically into the main legislative body of the country, the US Congress. And therein it lays the purpose of this article. We intend to investigate not only the historical presence of Hispanic legislators in Congress but also and especially their political influence in the current U.S. Congress. Finally, and prior to the conclusions drawn throughout the paper, we will analyze the political influence of the Hispanic congresswomen in the current 114th Congress. As we will be breaking down, this group has been changing gradually from a poor oppressed minority into one of the most dynamic groups of the country, introduced at all levels of government.
\end{abstract}

Keywords: Hispanic population, political presence, Hispanic Congresswomen, Hispanic political influence

\section{Introduction}

In the last legislative (mid-term) elections on November 4, 2014, the Hispanic population played decisive role, once more, in the shaping of the political landscape of the country. The different Hispanic candidates have shown that they can successfully pursue and achieve seats in both chambers of the Congress (House of Representatives and Senate).

While the Hispanics remain underrepresented both as voters and as elected candidates, American politicians are increasingly paying more attention to their potential as voters when it comes to influence the elections. Traditionally, Hispanics tend to prefer the Democratic Party and they share the same priorities as the majority of US citizens: a job, public education of quality and a proper health care. According to a survey carried out by the Pew Hispanic Center, more than $65 \%$ of Hispanic population voted for the Democratic Party.

In general, the Hispanic population suffer disproportionately high rates of poverty and unemployment, and many of them even also the lack of an adequate medical care. All these problems increase the incidence of crime in the Hispanic community so they see their upward social mobility limited. However, they are still escalating in the entrepreneurship and political framework of the country.

The present 114th Congress (2015-2017) opened its new session on January 3, 2015 with an unprecedented

Antonio Daniel Juan Rubio, Ph.D., Department of Languages, Centro Universitario de la Defensa de San Javier.

Isabel Maria Garcia Conesa, Ph.D., Department of Languages, Centro Universitario de la Defensa de San Javier. 
Hispanic representation summing up 37 members, including 3 senators and 34 representatives, of whom 9 are Hispanic women who all serve in the House of Representatives. Accordingly, Arturo Vargas (National Association of Elected \& Appointed Officials) issued the following statement: "Hispanics have demonstrated their power as well as voters at polls as Congress candidates" (Vargas, 2015). Following a research on the Hispanic representation, which was conducted by NALEO, there are nearly 6,100 Hispanics-serving in elected office nationwide.

Therefore, the main purpose of this article will be to proceed with the review of the Hispanic presence in the actual US Congress, laying special emphasis on the Hispanic women's presence on it. Not only won't we limit ourselves to establish their historical relevance but also we will enter into their role and their influence that such group plays today in US politics.

\section{Review of the State of Art: Historical Situation of Hispanics in the United States}

The last national census of 2010 confirmed that the Hispanic population in the United States had become the largest and fastest growing demographic minority group in the country, according to the data obtained from the official federal census (US Federal Bureau) (El Nasser, 2013, p. 1). It is also the most diverse, as suggested by the debate on the label "Hispanic" vs. "Latino".

The newly released census data confirm what the authors Sharon E. Ennis and Nora G. Albert said about the study of population in the country: "Hispanics represent over $50 \%$ of the population growth in the United States since 2000 until 2010, and now they represent more than $16 \%$ of the total population of the country with an estimated figure of 50.5 million people" (Ennis \& Albert, 2011, p. 2).

According to a projection carried out by a study of Elayne J. Heisler and Laura B. Shrestha, from the Congressional Research Service, the most recent population projections indicate that by 2050, the Hispanic population will total about 132.8 million people, which will represent around $30 \%$ of the total US population (Hessler \& Shrestha, 2011, p. 2).

This group, step by step, is becoming one of the most dynamic in the country and with the largest presence nationwide. But although they still remain underrepresented as voters or elected candidates, American politicians are paying increasing attention to their potential to influence the next presidential elections in 2016.

Despite the negative stereotypes that still exist in the American mass media means, Hispanics are participating in cultural exchange in various states, thus gaining visibility and presence in the American society. If Latino celebrities represent this role perfectly, residents of second and third generation are also integrated effectively into the country dynamics.

This growth tendency of the Hispanic population makes necessary the need to understand who they are and how they fit into the complex tapestry of American society and demographics. In fact, Hispanics have a unique place in the American landscape as a unified and heterogeneous population present in many regions of the country, mainly consisting of business owners, immigrants, and native politicians.

The term "Hispanic" first appeared in the 1970 Census and the word "Latino" developed later on as a grassroots movement, progressive and alternative. Historically, the term "Latino" has been used more in the western part of the country and the term "Hispanic" in the eastern part of it.

The term "Latino" refers to Latin America, a term coined in France in the 19th century to designate the Spanish and Portuguese-speaking America. Marcelo Suarez-Orozco, professor at the University of New York, and MarielaPaez, at the Boston College, said about the matter: "The same Latin term has only meaning in 
reference to the experience of the United States. Outside the country, we do not talk about Latinos, but Mexicans, Cubans, or Puerto Ricans" (Suárez-Orozco \& Paéz, 2009, p. 4).

Even within the United States itself, the merits of both terms are still widely debated. Both terms refer to an ethnic group rather than a race, an important but often misunderstood distinction. Race defines the geographical origin of the ancestry and the genetic similarity, while ethnicity refers to the common cultural heritage. Then, as defined by the Professor of Latin American studies at the University of Albany, Edna Acosta-Belen, "the Spanish term was created to describe a common heritage based on a language: Spanish" (Acosta-Belén, 1998, p. 74).

The office of the federal census defines a person of Hispanic, Latino, or Spanish origin "as a person of Cuban, Mexican, Puerto Rican, Central or South American culture, or another Spanish culture regardless of their race" (US Census Bureau, 2013). Therefore, the "Hispanic" and "Latino" terms are used synonymously.

The danger is that the two terms can homogenize the diverse experiences of their elements: members of different classes, races, languages, nationalities, religions, and gender. The emeritus Professor at the University of Colorado, Marta Gimenez, accurately described this challenge when she stated:

The problem the social scientists and public health specialists are facing when trying to make sense of the data collected by the laws is a problem not only of comparability but also of meaningless. The heterogeneity of the national origin groups undermines, in turn, generalizations about the whole group as such. (Oboler, 1997, p. 5)

In fact, Latino enclaves of different national origins thrive all over the map. According to scholars of political science Professors Joan Moore and Harry Pachon (Moore \& Pachon, 1985, p. 163), we find Mexicans and Central Americans in the Southwest, Cubans in Florida and Puerto Ricans and Dominicans in New York, among some other groups. For many individuals within these groups, their identity is determined by their national origin or any other factor, but rarely is called "Latino" or "Hispanic".

Because of their numerical proportion, Hispanics have the potential to be a powerful voting bloc. In fact, since the 1960s, the Hispanic vote has proved influential in both state and local laws and in legislative and presidential elections.

In the latter, the political candidates have taken special care to appeal to the Hispanic vote as the Hispanic population is mainly concentrated in five key states: California, New York, Florida, Texas, and Illinois. Such states, taken altogether, constitute more than half of the majority of the necessary votes for the election to the presidency.

However, several factors prevent their full political participation as well as their development into a unified voting bloc. One such factor is the youth of the Hispanic population. Following the opinion shared by Professor of history at California State University, Rodolfo Acuna, "the younger the community is, the less likely it is to take an active interest in the political culture" (Acuña, 1986, p. 156).

Therefore, the average age of the Hispanic population is 25.5 years, but some groups are even younger. For example, Mexican Americans are 21 years of average or Puerto Rican are 20. On the opposite side, the third largest group, the Cubans, has an average age of 35 years. Of these three groups, Cubans have shown, so far, the highest levels of political participation.

A second factor is the fact that a large segment of the legal Hispanic population cannot vote because they are not yet citizens of the United States. For example, according to the data collected by the Pew Hispanic Center, in the elections, $52 \%$ of all legal Hispanics in the country could not vote because they did not meet all the requirements set by the local or federal authorities (Pew Hispanic Center, 2013). 
Poverty is a third factor that affects the political participation. In opinion of historian Maurilio E. Vigil, who studies the political participation of Hispanics in the United States: "There is a direct correlation between the socioeconomic indicators such as the level of education or income, and the level of political participation" (Vigil, 1987, p. 208).

Therefore, as Hispanics have a higher poverty rate than other groups of Americans, they are less likely to participate in the political process, although it is likely that they would earn with their active participation. It can also be unrealistic to expect that the Hispanic population can become a powerful voting bloc due to the diversity of its population.

We should remember, at this point, that the Hispanic population includes individuals with ancestry from twenty different nations and their experiences in the United States are often too different. Even within the same group of Hispanics in the opinion of historians Moncadas and Juan Alberto Olivas, there may be significant regional, socio-economic, cultural, religious and racial differences (Moncadas \& Olivas, 2003, p. 95). And all this, of course, affects political behavior.

However, there are certain issues that can unite this diverse population at the local, state and national level. Legislation that promotes education and helps families generally receive strong support in Hispanic communities. Most Hispanics, for example, are committed to bilingual education as a means to help children.

Many Hispanics also support a comprehensive immigration reform, especially laws that target illegal immigration as a means to reduce competition for US native workers. The drafting of legislation on immigration that is fair, however, is still a challenge for the administration of the current Democratic President Barack Obama.

Although there have been several studies on the situation of the Hispanic community in the United States in recent decades from both sides of the Atlantic, these have been focusing mainly on demographic, developmental and educational aspects throughout history aspects.

But very few of these studies, we would dare say almost none, has focused exclusively on the numerical and symbolic representation of the community in the political arena and more specifically in the main legislative body, the Congress and in its influence in the legislative policy of the country.

Thus, we find numerous studies that deal with the demographic and numerical aspect of the Hispanic population in the United States. Among them, we can highlight the study of Professor at Cornell University, Maria Cristina Garcia, the one conducted by the prestigious Center for Demographic Studies Pew Hispanic Center in March 2011, or even the carried out by Navtej S. Dhaliwal at Rice University in September $2011^{1}$.

They have also conducted several studies on the effect of the Hispanic vote in the presidential elections, mainly in Spain. Thus, in this field, we can cite the study conducted by Professor of the University of Vigo José RuasAraujo, and the Professor at UNED Carmen Gonzalez Enriquez in October 2012, the gathered in the University of Alcala de Henares by LourdesTimoteo also in October 2012, or even the study of the sociologist Javier Paredes in November $2012^{2}$.

\footnotetext{
${ }^{1}$ Demographic studies on the Hispanic population in the United States: María Cristina García. Challenging the Melting Pot Ideology: The Hispanic/Latino Populations of the United States. Universidad de Cornell, 2004. Pew Hispanic Center. Census 2010: 50 Million Latinos Hispanics Account for More than Half of Nation's Growth in Past Decade. 2011. Navtej S. Dhaliwal. US Demographics: The Hispanic Boom. Pottomac Papers, United States Program, 2011.

${ }^{2}$ Studies on the Hispanic vote in the United States: José RúasAraujo. La creciente importancia del voto latino en las elecciones presidenciales de los Estados Unidos de América. Universidad de Vigo, 2012. Carmen Gonzáles Enríquez. El voto hispano en los Estados Unidos. UNED, 2012. Javier Paredes. El decisivo voto hispano en las elecciones presidenciales de Estados Unidos. Fundación Rafael Campalans, 2012. Lourdes Timoteo. La campaña electoral de Estados Unidos habla español. Universidad de Alcalá de Henares, 2012.
} 
Some other studies are related to the educational or historical evolution of the Hispanic population in the United States. For example, studies carried out in March and August 2012 by the White House, that of Professor Laura Agosta in September 2011, the one carried out by the Spanish diplomat Rafael Garranzo in June 2009, or the study performed by the Department of Commerce in September $2013^{3}$.

Finally, among the few studies that focus on the position of Hispanics in Congress we can mention the studies of the prestigious National Association of Elected and Appointed Officials (NALEO), and a brief overview appeared in the US press in early $2013^{4}$.

\section{The Hispanic Presence in the Actual U.S. Congress}

The incumbent 114th Congress (2015-2017) opened its biannual legislative period on January 3, 2015 with an unprecedented Hispanic presence in both its chambers: 34 in the House of Representatives \& 3 in the Senate. Along these 37 Hispanic members, among whom we can find 9 Hispanic women, we come across the following data by chambers: in the House of Representatives, 24 Hispanics belong to the Democratic Party, 9 to the Republican Party and 1 member to the New Progressive Party, while in the Senate, 2 senators belong to the Republican Party and 1 senator to the Democratic Party.

The 37 Hispanic members in the Congress represent the following 11 states: Arizona (2), California (13), Florida (4), Idaho (1), Illinois (1), New Jersey (2), New Mexico (2), New York (2), Northern Mariana Islands (1), Puerto Rico (1), Texas (6), Washington (1), and West Virginia (1). This complete information on the Hispanic presence in the actual US Congress can be gathered in Table 1:

Table 1

Hispanic Members in the US Congress

\begin{tabular}{|c|c|c|}
\hline State & House of Representatives & Senate \\
\hline Arizona & $\begin{array}{l}\text { Raul M. Grijalva (D) } \\
\text { Ruben Gallego (D) }\end{array}$ & \\
\hline California & $\begin{array}{l}\text { LucilleRoybal-Allard (D) } \\
\text { Xavier Becerra (D) } \\
\text { Grace F. Napolitano (D) } \\
\text { DevinNunes (R) } \\
\text { Dr. Raul Ruiz (D) } \\
\text { Linda Sanchez (D) } \\
\text { Loretta Sanchez (D) } \\
\text { Jim Costa (D) } \\
\text { Tony Cardenas (D) } \\
\text { Juan Vargas (D) } \\
\text { Norma Judith Torres (D) } \\
\text { David Valadao (R) } \\
\text { Peter Rey Aguilar (D) }\end{array}$ & \\
\hline Florida & $\begin{array}{l}\text { Mario Diaz-Balart (R) } \\
\text { Ileana Ros-Lehtinen (R) } \\
\text { Carlos Curbelo (R) }\end{array}$ & Marco Rubio(R) \\
\hline
\end{tabular}

\footnotetext{
${ }^{3}$ Studies on the historical and educative evolution of the Hispanic population: The White House. An America Built to Last: White House Hispanic Community. Interim Report, 2012. The White House. President Obama's Agenda and the Hispanic Community. 2012. Laura Agosta. 50.5 million people in search of a better education: The situation of Hispanics in the US educational system. Formar Foundation, 2011. Rafael Garranzo. El creciente peso de los hispanos en Estados Unidos y su significación para España. 2009. US Department of Commerce. We, the American Hispanics. Economics and Statistics Administration, Bureau of the Census, 2003.

${ }^{4}$ Studies about Hispanics in the US Congress: National Association of Latino Elected and Appointed Officials. 2012 Election Latino Opportunities in Congress: Profile of Latino Congressional Candidates. NALEO Educational Fund, 2012. The Associated Press. New Congress with record number of Latinos to be sworn in today. 2013.
} 
(Table 1 continued)

\begin{tabular}{|l|l|l|}
\hline State & House of Representatives & Senate \\
\hline Idaho & Raul Labrador (R) & \\
\hline Illinois & Luis V. Gutierrez (D) & Robert Menendez (D) \\
\hline New Jersey & Albio Sires (D) & \\
\hline New Mexico & $\begin{array}{l}\text { Ben Lujan (D) } \\
\text { Michelle Lujan Grisham (D) }\end{array}$ & \\
\hline New York & $\begin{array}{l}\text { Josi E. Serrano (D) } \\
\text { Nydna M. Velazquez (D) }\end{array}$ & \\
\hline $\begin{array}{l}\text { Northern Mariana } \\
\text { Islands }\end{array}$ & Gregorio Sablan (D) & Ted Cruz (R) \\
\hline Puerto Rico & Pedro Pierluisi (New Progressive) & \\
\hline Texas & $\begin{array}{l}\text { Joaquin Castro (D) } \\
\text { Ruben Hinojosa (D) } \\
\text { Henry Cuellar (D) } \\
\text { Bill Flores (R) } \\
\text { Filemon Vela (D) }\end{array}$ & \\
\hline Washington & Jaime Herrera Beutler (R) & \\
\hline West Virginia & Alex X. Mooney (R) & \\
\hline
\end{tabular}

Notes. R: Republican Party; D: Democrat Party.

Besides their numerical presence, their political relevance is remarked in their appointment to some of the most important committees in both chambers of Congress. Since we will specifically be dealing with the case of the 9 Hispanic women in the next section, we will just focus at this point on the relevance of the Hispanic congressmen in Congress.

\section{Hispanics in the Senate}

In the actual U.S. Senate, we come across the presence of 3 Hispanic members: Marcos Rubio, Bob Menendez and Ted Cruz. Incidentally enough, it is the chamber in which there are more Hispanic members belonging to the Republican Party.

In Table 2 we can find out the most relevant information about each one of these 3 Hispanic senators: the state they represent, the party they belong to, their term in office, the committees in which they have been appointed, and what their main scope of interest is on behalf of their lobbying function.

Table 2

List of Hispanic Members in the US Senate

\begin{tabular}{|l|l|l|}
\hline Senator & Committee & Lobbies \\
\hline $\begin{array}{l}\text { Ted Cruz } \\
\text { Republican - Texas, 2013) }\end{array}$ & $\begin{array}{l}\text { Armed Services } \\
\text { Judiciary } \\
\text { Commerce, Science \& Transportation } \\
\text { Rules \& Administration }\end{array}$ & $\begin{array}{l}\text { fight against discrimination, reduce } \\
\text { government body }\end{array}$ \\
\hline $\begin{array}{l}\text { Marcos Rubio } \\
\text { Republican - Florida, 2011) }\end{array}$ & $\begin{array}{l}\text { Commerce, Science \& Transportation } \\
\text { Foreign Relations } \\
\text { Small Business \& Entrepreneurship } \\
\text { Select Committee on Intelligence }\end{array}$ & $\begin{array}{l}\text { vice-president of Senate Committee of } \\
\text { Republican Party }\end{array}$ \\
\hline $\begin{array}{l}\text { Bob Menendez } \\
\text { (Democratic - New Jersey, 2005) }\end{array}$ & $\begin{array}{l}\text { Foreign Relations (President) } \\
\text { Finance } \\
\text { Banking, Housing \& Urban Affairs }\end{array}$ & $\begin{array}{l}\text { defence of national security, immigration } \\
\text { system }\end{array}$ \\
\hline
\end{tabular}




\section{Hispanics in the House of Representatives}

In the actual U.S. House of Representatives, we come across the presence of 34 Hispanic members: 24 belong to the Democratic Party, 9 to the Republican Party and 1 to the New Progressive Party. Again, we will just focus our attention on the Hispanic men in the House of Representatives.

In Table 3 we can find out the most relevant information about each one of these Hispanic representatives: the state they represent, the party they belong to, their term in office, the committees in which they have been appointed, and what their main scope of interest is on behalf of their lobbying function. However, we will examine all these Hispanic members according to the state they represent, alphabetically arranged.

Table 3

List of Hispanic Members in the US House of Representatives

\begin{tabular}{|c|c|c|c|}
\hline State & Representative & Committee & Lobbies \\
\hline \multirow[t]{2}{*}{ Arizona } & $\begin{array}{l}\text { Raul M. Grijalba } \\
\text { (Democratic - 2003) }\end{array}$ & $\begin{array}{l}\text { Education and the Workforce } \\
\text { Natural Resources }\end{array}$ & $\begin{array}{l}\text { reform of mining and environmental bills } \\
\text { and education }\end{array}$ \\
\hline & $\begin{array}{l}\text { Ruben Gallego } \\
(\text { Democratic - 1991) }\end{array}$ & $\begin{array}{l}\text { Appropriations } \\
\text { Select Permanent Intelligence }\end{array}$ & civil rights, discrimination, immigration \\
\hline \multirow[t]{8}{*}{ California } & $\begin{array}{l}\text { Peter Rey Aguilar } \\
\text { (Democratic }-2015\end{array}$ & $\begin{array}{l}\text { Agriculture } \\
\text { Armed Services }\end{array}$ & $\begin{array}{l}\text { middle-class families, fair legislation, } \\
\text { programs for senior and veterans }\end{array}$ \\
\hline & $\begin{array}{l}\text { Juan Vargas } \\
(\text { Democratic - 2013) }\end{array}$ & $\begin{array}{l}\text { Agriculture } \\
\text { Foreign Affairs } \\
\text { House Administration }\end{array}$ & $\begin{array}{l}\text { finance, immigration, federal aid } \\
\text { programs }\end{array}$ \\
\hline & $\begin{array}{l}\text { Tony Cardenas } \\
\text { (Democratic - 2013) }\end{array}$ & $\begin{array}{l}\text { Natural Resources } \\
\text { Budget } \\
\text { Oversight \& Government Reform }\end{array}$ & immigration, fiscal affairs \\
\hline & $\begin{array}{l}\text { Raul Ruiz } \\
\text { (Democratic-2013) }\end{array}$ & \begin{tabular}{|l|} 
Natural Resources \\
Veterans' Affairs \\
\end{tabular} & medical care investigation, solar energy \\
\hline & \begin{tabular}{|l|} 
Devin Nunes \\
(Republican - 2013)
\end{tabular} & $\begin{array}{l}\text { Permanent Committee on } \\
\text { Intelligence }\end{array}$ & water, energy, federal spending, veterans \\
\hline & $\begin{array}{l}\text { Jim Costa } \\
(\text { Democratic - 2013) }\end{array}$ & $\begin{array}{l}\text { Agriculture } \\
\text { Natural Resources }\end{array}$ & water, agriculture, economy \\
\hline & $\begin{array}{l}\text { David Valadao } \\
\text { (Republican - 2013) }\end{array}$ & Appropriations & agriculture, energy, water \\
\hline & $\begin{array}{l}\text { Xavier Becerra } \\
(\text { Democratic - 1993) } \\
\end{array}$ & $\begin{array}{l}\text { Ways \& Means } \\
\text { Joint Select Deficit Reduction }\end{array}$ & immigration, women's rights, abortion \\
\hline \multirow[t]{2}{*}{ Florida } & $\begin{array}{l}\text { Carlos Curbelo } \\
\text { (Republican - 2015) }\end{array}$ & $\begin{array}{l}\text { Education and the Workforce } \\
\text { Small Business } \\
\text { Transport and Infrastructure }\end{array}$ & education, transport \\
\hline & $\begin{array}{l}\text { Mario Diaz-Balart } \\
\text { (Republican - 2009) }\end{array}$ & Appropriations & Cuba blockade \\
\hline Idaho & $\begin{array}{l}\text { Raul Labrador } \\
\text { (Republican - 2006) }\end{array}$ & $\begin{array}{l}\text { Natural Resources } \\
\text { Judiciary }\end{array}$ & $\begin{array}{l}\text { immigration, education, energy and } \\
\text { agriculture }\end{array}$ \\
\hline Illinois & $\begin{array}{l}\text { Luis V. Gutierrez } \\
\text { (Democratic - 1993) }\end{array}$ & \begin{tabular}{|l|} 
Financial Services \\
Permanent Select Intelligence
\end{tabular} & $\begin{array}{l}\text { independence of Puerto Rico, workers' } \\
\text { rights }\end{array}$ \\
\hline New Jersey & $\begin{array}{l}\text { Albo Sires } \\
(\text { Democratic - 2000) }\end{array}$ & $\begin{array}{l}\text { Transport and Infrastructure } \\
\text { Foreign Affairs }\end{array}$ & public transport and housing \\
\hline New Mexico & $\begin{array}{l}\text { Ben Lujan } \\
\text { (Democratic-2009) }\end{array}$ & Science, Space \& Technology & bills against piracy, health system \\
\hline New York & $\begin{array}{l}\text { Jose E. Serrano } \\
(\text { Democratic - 1999) }\end{array}$ & Appropriations & $\begin{array}{l}\text { public education, immigration, Puerto } \\
\text { Rico independence }\end{array}$ \\
\hline $\begin{array}{l}\text { Northern Mariana } \\
\text { Islands } \\
\end{array}$ & $\begin{array}{l}\text { Gregorio Sablan } \\
\text { (Democratic - }\end{array}$ & $\begin{array}{l}\text { Education and the Workforce } \\
\text { Natural Resources }\end{array}$ & $\begin{array}{l}\text { funds and water to his district, } \\
\text { immigration }\end{array}$ \\
\hline Puerto Rico & $\begin{array}{l}\text { Pedro Pierluisi } \\
\text { (New Progressive - }\end{array}$ & \begin{tabular}{|l} 
Judiciary \\
Natural Resources
\end{tabular} & Income equality, credit equity \\
\hline
\end{tabular}


(Table 3 continued)

\begin{tabular}{|l|l|l|l|}
\hline State & Representative & Committee & Lobbies \\
\hline \multirow{5}{*}{ Texas } & $\begin{array}{l}\text { Joaquin Castro } \\
\text { (Democratic - 2013) }\end{array}$ & $\begin{array}{l}\text { Armed Services } \\
\text { Foreign Affairs }\end{array}$ & education, justice \\
\cline { 2 - 4 } & $\begin{array}{l}\text { Filemon Vela } \\
(\text { Democratic - 2013) }\end{array}$ & $\begin{array}{l}\text { Agriculture } \\
\text { Homeland Security }\end{array}$ & health attention, workers' rights \\
\cline { 2 - 4 } & $\begin{array}{l}\text { Bill Flores } \\
\text { Republican - 2009) }\end{array}$ & $\begin{array}{l}\text { Natural Resources } \\
\text { Veterans' Affairs }\end{array}$ & tax reduction, abortion rights, nuclear plants \\
\cline { 2 - 4 } & $\begin{array}{l}\text { Henry Cuellar } \\
\text { (Democratic - 2005) }\end{array}$ & $\begin{array}{l}\text { Agriculture } \\
\text { Homeland Security }\end{array}$ & $\begin{array}{l}\text { public education, health system, } \\
\text { homeland security }\end{array}$ \\
\cline { 2 - 4 } & $\begin{array}{l}\text { Ruben Hinojosa } \\
\text { (Democratic - 1997) }\end{array}$ & $\begin{array}{l}\text { Education \& the Workforce } \\
\text { Financial Services }\end{array}$ & minority groups, water conservation \\
\hline West Virginia & $\begin{array}{l}\text { Alex X. Mooney } \\
\text { Republican - }\end{array}$ & $\begin{array}{l}\text { Natural Resources } \\
\text { Budget }\end{array}$ & pro-life values, less spending, lower taxes \\
\hline
\end{tabular}

\section{Hispanic Women in the House of Representatives}

Of the 104 women serving in the 114th Congress, 9 are Hispanic: 7 Democrat and 2 Republican. These 9 Hispanic women represent 5 different states: California (5), Florida (1), New Mexico (1), New York (1), and Washington (1).

In Table 4 we can summarise the names of these 9 Hispanic women, the party they belong to, their respective state and the term they have been serving in office. As it can be checked out, one of these women, Ileana RosLehtinen, has been serving in Congress for more than 25 years.

Table 4

Hispanic Women in the Us Congress

\begin{tabular}{|l|l|l|l|}
\hline Representative & State & Party & Term in office \\
\hline Ileana RosLehtinen & Florida & Republican & $1989-$ present \\
\hline Lucille Roybal-Allard & California & Democratic & $1993-$ present \\
\hline Nydia Velazquez & New York & Democratic & $1993-$ present \\
\hline Loretta Sanchez & California & Democratic & $1997-$ present \\
\hline Grace Napolitano & California & Democratic & $1999-$ present \\
\hline Linda Sanchez & California & Democratic & $2003-$ present \\
\hline Jaime Herrera Beautler & Washington & Republican & $2011-$ present \\
\hline Michelle Lujan Grisham & New Mexico & Democratic & $2013-$ present \\
\hline Norma Torres & California & Democratic & $2015-$ present \\
\hline
\end{tabular}

We will now focus in more detail on each one of these 9 Hispanic women, ranging from the oldest to the newest serving in office. Not only will we put an emphasis on the general data belonging to each congresswoman but also we will consider what their main interests are and, specifically, what committees they have been appointed into.

And the longest-serving Hispanic woman in Congress is Ileana Ros-Lehtinen, who was born in Havana (Cuba) on July, 15, 1952, and who has been serving in Congress since 1989 (26 years). She represents the 27th district of Florida and she belongs to the Republican Party. She holds the honour of being the first Hispanic woman in Congress.

She began her career as a certified teacher in Florida, turning into the principal of a private bilingual elementary school later on. At first she entered public service so as to fight for a stronger educational system, 
lower taxes and a brighter economic future for her constituents.

Prior to her service in the national Congress, she was elected to the Florida State House of Representatives in 1982 and the Florida Senate in 1986, becoming then the first Hispanic woman to serve in either body. Later on she was elected to the US House of Representatives in 1989 following a special election to fill the seat held by the late Claude Pepper. And she has been serving there ever since.

As the economy remains a pressing issue for so many families, she supports reducing taxes and cutting down unnecessary government spending. She also supports plans to balance the federal budget and to increase tax incentives for small businesses and middle class families.

And given her professional background in education, she has tirelessly worked to strengthen the "Head Start" program, whose aim is to increase the availability to student financial aid.

She is also a strong advocate of programs that address the serious problem of domestic violence against women, being a lead sponsor of the reauthorization of the "Violence against Women Act", which increases the resources towards the prosecution of domestic violence, dating violence and sexual assault. Eventually, she also supports legislation to increase criminal penalties for perpetrators of Medicare fraud, which in her opinion, is a deplorable practice which robs hardworking seniors of the benefits they spent a lifetime earnings whilst, at the same time, wastes billions in taxpayer dollars.

As the wife of a Vietnam veteran and step-mother to Marine aviators, she has been appointed to the following committees: Foreign Affairs (Chairman of the Subcommittee of Middle East and North Africa) and the Permanent Committee on Intelligence. One of her main goals is to improve the nation's military, safeguarding veteran's health care and ensuring that returning veterans have access to a college education. She also authorised legislation awarding the Congressional Gold Medal to the "Women Airforce Service Pilots" (WASP), who had been denied recognition for their service during World War II.

The second Hispanic congresswoman is Lucile Roybal-Allard, who became the first Mexican-American woman elected to Congress in 1992. She was born on June 22, 1941 in Boyle Heights (California) and she has been representing the 40th district of California for 22 consecutive years. She has also been the first Hispanic to serve in the House Appropriations Committee, and the first to serve as a chair or ranking member on a House Appropriations Subcommittee.

She has worked tirelessly to create jobs, to improve health services and to create stronger, better educational opportunities for her constituents. She also ranks as one of the House's foremost supporters of an adequate immigration reform, a strong homeland security system, strong labour unions and the rights of women and children.

From her position, she has secured millions of dollars to create jobs on much-needed local construction and transportation projects. She has also been at the forefront of the fight to improve the quality and affordability of health services and she has successfully secured funding for local health needs and local education.

Besides, she serves as a House Democratic Senior Whip and is a member of the following caucuses: the Congressional Hispanic Caucus (CHC), the Congressional Progressive Caucus (CPC), the Congressional Asian Pacific American Caucus (CAPAC) and the Democratic Outreach and Engagement Task Force.

Her main accomplishments include the following: creating jobs for her Congressional District, increasing the fairness of the immigration system and protecting the homeland (Dream Act), fighting for a healthier district (Sober Truth on Preventing Underage Drinking Act, 2007, Newborn Screening Saves Lives Act, 2008, 
Health Equity and Accountability Act, 2014) and strengthening our schools and workforce (Children's Act for Responsible Employment).

The third Hispanic congresswoman is Nydia Velazquez, who is currently serving her twelfth term in the House of Representatives representing the 7th district of New York. Incidentally enough, in the 114th Congress, she is the ranking member of the House Small Business Committee and she is a senior member of the Financial Services Committee.

She was born on March, 28, 1953 in Yabucoa (Puerto Rico) and became the first person in her family to receive a college diploma. She graduated magna cum laude in 1974 with a degree in political science at the University of Puerto Rico. After earning a master's degree on scholarship, she taught Puerto Rican studies in 1981.

In 1992, she was the first Puerto Rican woman elected to the House of Representatives and in 1998 she was named ranking Democratic member of a full house committee, making her the first Hispanic woman to serve as a Ranking Member. In 2006, she was even named chairwoman of the House Small Business Committee, making her the first Hispanic to chair a full congressional committee.

As a fighter for equal rights of the underrepresented and a proponent of economic opportunity for the working class and the poor, she combines sensibility and compassion, since she works to encourage economic development, to protect community health and the environment, to combat crime and worker abuses, and to secure access to affordable housing, quality education and health care for all families.

She also has established numerous small business legislative priorities, encompassing the areas of tax, regulations, access to capital, federal contracting opportunities, trade, technology, health care and pension reform. As a landmark of her notoriety, she was named as the "Woman of the Year" by the Hispanic Business Magazine in recognition of her national influence in both the political and business sectors and for her long-time support of minority enterprise.

The fourth Hispanic congresswoman is Loretta Sanchez, who was born on January 7, 1960 in Lynwood (California). She has been representing the 46th district of California in the US House of Representatives since 1997. She is currently serving her tenth term in office, holding senior positions on the House Armed Services Committee and the House Homeland Security Committee. She is also a member of the Congressional Hispanic Caucus and she serves as the co-chair of the Immigration Task Force.

She is a recognised leader on military and national security issues, currently serving as the ranking member of the Tactical Air and Land Forces Subcommittee. She is also a member of the Subcommittee on Strategic Forces.

As the founder and co-chair of the Women in the Military Caucus, she advocates for female service members to serve in combat roles and fights to stamp out sexual assault in the armed forces. She even passed a long-shot bill that updated sexual assault provisions in the Uniform Code of Military Justice, as well as a bill to create a sexual assault database.

She also served on the House Homeland Security Committee and is now the committee's second ranked Democrat. She serves on the Subcommittee on Border and Maritime Security as well as the Subcommittee on Cybersecurity, Infrastructure Protection and Security Technologies.

Besides her congressional work, she is committed to facilitating job creation, reducing crime, supporting quality educational opportunities, and increasing access to affordable health care for her constituents. As a proof of this, she regularly visits schools and businesses and meets with residents around. 
The fifth Hispanic congresswoman is Grace Napolitano, who belongs to the Democratic Party, born on December, 4, 1936 in Brownsville (Texas). She has represented the 32nd district of California in the US House of Representatives for 16 years.

Best known for her grandmotherly image, she has a reputation as a caretaker. She prides herself on being responsive to the needs of her constituents and fiercely protective of federal resources used by those under her watch. Since water is always a pressing concern for California, she is the top Democrat on the Transportation and Infrastructure Subcommittee on Water Resources and Environment, being able to successfully moving water legislation through the Republican-controlled House.

She enjoys favourable ratings from environmental groups and she backs strong state and federal water quality standards. In that vein, she strongly opposes hydraulic fracturing, the injection of high-pressure fluids into rock layers to allow access to new deposits of gas and oil. She also pays a lot of attention to railroad safety and she has fought to maintain the funding and schedule for the implementation of positive train control systems. She also has a passion for mental-health issues. Consequently, she has proposed creating a competitive grant program for schools that partner with community groups to increase student access to mental-health resources.

The sixth Hispanic congresswoman is Linda Sanchez, born on January, 28, 1969 in Orange (California). Belonging to the Democratic Party, she has served in the US House of Representatives for 12 years serving the 38th district of California. She is recognised by her colleagues as a leading voice for working families, judiciary and trade matters.

She has broken many barriers in Congress, including becoming the first Hispanic to serve on the House Judiciary Committee. She was also the first Hispanic in history to serve on the House Ways and Means Committee. Currently, she is the ranking member on the House Ethics Committee where she helps guarantee that the American people can have faith and confidence in their elected leaders. She also serves on the powerful and prestigious House Committee on Ways and Means, which plays a critical role in federal legislation on trade, social security and Medicare.

Sanchez has tirelessly worked to ensure that workers are safe on the job from industrial accidents as well as from employer intimidation and retaliation. Keeping children safe online has also been a priority for her, introducing as a result legislation to criminalize cyber bullying and to reduce bullying, harassment and gang activity in the schools.

She is committed to reducing crime, making schools safe, providing quality education and affordable health care, improving the economy by creating new opportunities, and cleaning up the air and water. Her life-long commitment to progressive issues is reflected in her record to protect a woman's right to choose, to protect and expand civil rights and voting rights, to promote clean energy and green jobs, and to reform the country's immigration laws.

The seventh Hispanic congresswoman is Jaime Herrera Beutler, who is one of the two women who belong to the Republican Party. She was born on November, 3, 1978 in Glendale (California), and she has been representing the 3rd district of Washington in the US House of Representatives for 4 years, being one of the youngest women in Congress.

National Journal included her on their list of "The Top 25 Most Influential Washington Women under 35". She is also the first Hispanic in history to represent Washington and the first bill that she introduced in Congress was to cut down the salaries of members of Congress, the President and the Vice-president by $10 \%$. 
She has developed a record of working productively with both Republicans and Democrats alike on important issues. During her first term in Congress, she introduced the "Small Business Opportunities Act", a bipartisan reform to the federal contracting process that increases opportunities for thousands of America's small businesses.

Her top priority in Congress is job creation. She is working hard to find solutions to the problem of unemployment nationwide, stating the following: "I will do everything I can to get the folks back to work". Another priority is to give tax relief to business owners serving in the military, for which she has learned the value of common sense solutions that work for people instead of partisan bickering.

The eighth Hispanic congresswoman is Michelle Lujan Grisham, who was just elected to the US House of Representatives in the 113th Congress, thus serving on it for a couple of years. She was born on October, 24, 1959 in Los Alamos (New Mexico) and she represents the first district of such state.

Belonging to the Democratic Party, she has dedicated her life to serving her community, to fighting for seniors and building an economy that works for all. Her grandfather was the first Hispanic Chief Justice of the New Mexico Supreme Court, a passion for law which she inherited attending a law school and becoming an attorney herself.

She fights to protect seniors from scam artists, to safeguard them from abuse and neglect, and to help them to remain in their homes. Currently, she serves on the House Committee on Agriculture, the House Committee on the Budget and the House Committee on Oversight and Government Reform.

Finally, the newest Hispanic woman in Congress is Norma Torres, who is just serving her first term in office in the 114th Congress. Belonging to the Democratic Party, she represents the 35th district of California, despite having being born in Escuintla (Guatemala) on October, 24, 1959.

Throughout her career in elected office, she has worked to make government more responsive to the needs of residents. She also led efforts to increase access to care and improve the quality of care in underserved areas. She even championed a law to generate more revenue for programs that train and place doctors in medically underserved communities.

In Congress, she led efforts to provide financial assistance to millions of families negatively impacted by the great recession. Fighting crime and making sure the public safety system is responsive to the need of the community has also been a lifelong priority for her. She also authored legislation to help prevent metal theft, keep drivers under the influence of drugs off the roads and highways, and to raise fines on criminals who tamper with online data.

\section{Conclusions}

The main obstacle to assimilation is not cultural but economic. As new generations of Hispanics develop and move up into the economic and social scale of the country, large segments of the population, originally immigrant, has been Americanized. As the Hispanic community becomes permanent resident of the country, it tends to be more involved in various political processes in order to try to improve their situation.

Along this article we have proved how the Hispanic population not only experienced spectacular demographic growth in the country, but it also experienced an active participation in the actual U.S. Congress. The current 114th Congress holds the record number of Hispanic members in its both chambers: 3 Senators \& 34 Representatives. This makes up a milestone unparalleled in the history of both chambers.

So far we have been checking how different Hispanics have been incorporated into all levels of the federal 
government, appointed to some of the most prestigious committees of both Houses, which clearly reflects their relevance in the current US political system.

Their political relevance is remarked in the increasing number of Hispanic women who are serving in the Congress: 9 Hispanic women, of whom 7 are Democrat and 2 Republican. These 9 Hispanic women represent 5 different states: California (5), Florida (1), New Mexico (1), New York (1), and Washington (1).

In Table 5, there is a brief check-list summary of the most important highlights of theseHispanic women members in Congress:

Table 5

Highlights of Hispanic Women in the US Congress

\begin{tabular}{|c|c|}
\hline Representative & Highlights \\
\hline Ileana Ros Lehtinen & $\begin{array}{l}\text { 1st Hispanic woman in Congress } \\
\text { committed to improving lives of constituents }\end{array}$ \\
\hline LucilleRoybal-Allard & $\begin{array}{l}\text { 1st Mexican-American woman in Congress } \\
1 \text { st Hispanic to serve on House Appropriations Committee }\end{array}$ \\
\hline Nydia Velazquez & $\begin{array}{l}\text { 1st Puerto Rican woman in Congress } \\
1 \text { st Hispanic woman to serve as Ranking Member }\end{array}$ \\
\hline LorettaSanchez & $\begin{array}{l}\text { leader on military \& national security issues } \\
\text { founder of Women in Military Caucus }\end{array}$ \\
\hline Grace Napolitano & reputation as caretaker, responsive to needs of constituents \\
\hline Linda Sanchez & $\begin{array}{l}\text { 1st Hispanic on Ways and Means Committee } \\
\text { leading voice for working families }\end{array}$ \\
\hline Jaime Herrera Beautler & 1st Hispanic to represent Washington, one of youngest women \\
\hline Michelle Lujan Grisham & advocate of seniors \& elderly \\
\hline Norma Torres & responsive to needs of residents \\
\hline
\end{tabular}

\section{References}

Acosta-Belén, E. (1998). The Hispanic experience in the United States. New York: Praeger.

Acuña, R. (1986). Occupied America: A history of chicanos. New York: Harper-Collins.

Agosta, L. (2011). 50.5 million people in search of a better education: The situation of Hispanics in the US educational system.

Formar Foundation.

Dhaliwal, N. S. (2011). US Demographics: The Hispanic Boom. Pottomac Papers, United States Program.

El Nasser, H. (2013). 39 Million make Hispanics the largest US minority group. USA Today.

Ennis, S. E., \& Albert, N. G. (2011). The Hispanic population: 2010. Washington: US Census Bureau, Department of Commerce.

García, M. C. (2004). Challenging the melting pot ideology: The Hispanic/Latino populations of the United States. Universidad de Cornell.

Garranzo, R. (2009). El creciente peso de los hispanos en Estados Unidos y su significación para España (The growing influence of Hispanics in the United States and their significance for Spain). Fundación Carolina.

Gonzáles Enríquez, C. (2012). El voto hispano en los Estados Unidos (The Hispanic vote in the United States). UNED.

Hessler, E. J., \& Shrestha, L. B. (2011). The changing demographic profile of the United States. Congressional Research Service.

Moncadas, A., \& Olivas, J. (2003). Hispanos 2000. Madrid: Ediciones Libertarias.

Moore, J., \& Pachon, H. (1985). Hispanics in the United States. New York: Prentice-Hall.

National Association of Latino Elected and Appointed Officials. (2012). 2012 Election Latino Opportunities in Congress: Profile of Latino Congressional Candidates. NALEO Educational Fund.

Oboler, S. (1997). Ethnic labels, Latino lives identitity and the politics of representation in the United States. Minneapolis: University of Minnesota.

Paredes, J. (2012). El decisivo voto hispano en las elecciones presidenciales de Estados Unidos (The decisive Hispanic vote in the US presidential elections). Fundación Rafael Campalans.

Pew Hispanic Center. (2011). Census 2010: 50 Million Latinos Hispanics account for more than half of nation's growth in past decade. Washington: Pew Hispanic Center. 
Pew Hispanic Center. (2013). Between two worlds: How young Latinos come of age in America. Washington: Pew Hispanic Center.

Rúas Araujo, J. (2012). La creciente importancia del voto latino en las elecciones presidenciales de los Estados Unidos de América (The increasing importance of the Latino vote in the presidential elections of the United States of America). Universidad de Vigo.

Suárez-Orozco, M. M., \& Paéz, M. (2009). Remaking America. California: University of California Press.

The White House. (2012). An America built to last: White House Hispanic community. Interim Report.

The White House. (2012). President Obama's agenda and the Hispanic community. Interim Report.

Timoteo, L. (2012). La campaña electoral de Estados Unidos habla español (The electoral campaign of the United States speaks Spanish). Universidad de Alcalá de Henares.

US Census Bureau. (2013). 2010 US Census. Washington: US Department of Commerce.

US Department of Commerce. (2003). We, the American Hispanics. Economics and Statistics Administration, Bureau of the Census.

Vigil, M. E. (1987). Hispanics in American politics. Lanham, MA: University Press of America. 